\title{
IMPLEMENTATION OF THE BALANCED SCORECARD AS A PERFORMANCE MEASURE STKIP PGRI TULUNGAGUNG
}

\author{
Tutut Suryaningsih; Novita Eka Muliawati
}

\begin{abstract}
ABS TRACT
Competition between universities in the age of globalization is increasingly tight. Univer sities vying to improve its quality so that the confidence of customers, in this case prospective students is increasing. Therefore we need a performance measurement system that can be used by management to evaluate the performance and the performance of the existing business processes in college. The results of this evaluation will be very important to plan and determine the steps and strategies to achieve the strategic vision, mission, and goals of the institution. One method that can be used as a performance measure is balanced scorecard method. In the balanced scorecard, performance is not only seen from the financial aspect, but also other aspects beyond the financial aspects of the support and influence on the financial aspects, namely the customer, internal business processes, and learning and growth. Therefore, the purpose of this study is to implement the Balanced Scorecard method for measuring the performance STKIP PGRI Tulungagung.The end result of this implementation is a company scorecard is a scorecard (performance measurement tool) consisting of strategy, performance measures, targets to be achieved, which are grouped into each section in STKIP PGRI Tulungagung viewed from four perspectives on the balanced scorecard.
\end{abstract}

Keywords: performance measurement, balanced scorecard, college, STKIP PGRI Tulungagung, company scorecard

The performance assessment is essential for universities who want to stay ahead and compete in both the national and global arena. To win the competition, the performance of an organization of higher education should reflect an improvement over a period eke next period. During this frequently used is the traditional performance measures that only focus on the financial sector alone.

These financial statements are the most widely used information as a basis for measuring the performance of organizations, especially financial performance. Accounting measures used are ratios, both relating to certain items in the balance sheet or income statement, either individually or a combination of the two reports (Munawir: 1998). It is with this consideration, the ratio is a measure of organization prospects for the future (Syafarudin: 1996). So there was a financial ratios such as liquidity ratios, leverage ratios, activity ratios, profitability ratios and other ratios (Riyanto: 1997). The financial measure is believed to be the primary measurement tool.

In the further development of performance measurement that exist now (just rely on financial measures) felt had to be changed. They then develop a performance measure new that is not only based on the perspective of financial (financial perspective) but also from the perspective of the customer (customer perspective), business process internally (internal business process perspective) as well as spending and growth (learning and growth perspective) (Kaplan
Norton : 1992). Fourth perspective measurements are then known as the Balanced Scorecard (BSC).

BSC as well as traditional performance measurement still use financial measures such as the company's ability to generate profits, ROI, cashflows and others. These financial measures tell only a past event that is considered sufficient for the company's industrial era which considers that the ability of long-term investments and relationships with customers not meruapakan a critical success factor. BSC using a causal approach to try to trace that profits as a result of a series of strategies and elaboration of missions applied by the company. Performance measures the company's ability generated from the acquired customer loyalty because customers are satisfied with the products and services it receives (balanced with the sacrifice of issuance or customer value). Customer satisfaction (customer satisfaction) is caused by the quality (quality) products and services are delivered in a timely manner (on time delivery) at competitive rates or cheap (low cost). Products or services produced by the internal business processes that constantly innovate and repair (continouos improvement) in accordance with the wishes of the customer (customer needs). Furthermore, a successful internal business processes supported by the ability of employees increased as the empowerment of workers in the form of education and training.

Private university as an organization or a service company is expected to provide the satisfaction of services to students. Satisfaction is spearheading management success. Then it must be measured by the BSC approach. But in addition to 
customer satisfaction, university performance can also be measured by the BSC (Financial perpective, Internal Process, Learning and Growth perpective).

Performance measurement is performed with further useful perspective Balanced Scorecard to translate the vision and mission of an organization including private university. This interpretation is important in order to formulate strategic goals and objectives which will then be operationalized into a work program. With the work program, the private university can increase its performance can further achieve the ideals embodied in the vision and mission.

Efforts to implement the concept of the balanced scorecard in performance measurement private university should be made to formulate appropriate strategies to improve the performance of private university is concerned.

As described in the background, this study will implement a balanced method scorecrad as a measurement of performance STKIP PGRI Tulungagung. The formulation of the problem to be solved by doing this research are:

How to measure performance and evaluate the performance of STKIP PGRI Tulungagung on four perspectives, namely financial, customer, internal business processes, and learning and growth.

To determine the extent of the use of perspective Balanced Scorecard in translating the vision, mission in Tulungagung PGRI STKIP strategy and efforts made STKIP PGRI Tulungagung to improve performance by implementing the strategy Balanced scorecard perspective.

Comprehensive measurement system that includes aspects of financial and non-financial aspects have been designed by Robert S. Kaplan and David P. Norton called Balanced Scorcard. Balanced Scorecard to educate management and organization to look at the overall company from four perspectives: financial, customer, internal business processes, and learning and growth.

Balanced scorecard consists of two words, namely the scorecard (scorecard) and balanced (balanced). The scorecard is a card that is used to record the score results of a person's performance / personnel and plan your score to be achieved in the future. The comparison between the plan defined by the actual results achieved are used to conduct the evaluation. While the word impartial shows that the performance of such personnel impartial measured from two aspects of both financial and non-financial, long-term and short-term, internal and external.

In the balanced scorecard, there are four different perspectives of a company's activities to be evaluated, namely: a) the financial perspective; b) customer perspective; c) internal business process perspective; d) learning and growth perspective.

\section{METHODS}

This study is a qualitative research because it uses the Balanced Scorecard as a strategic implementation tool in the effort to improve the performance STKIP PGRI Tulungagung. A qualitative approach was selected in order to obtain a result that is closer to reality. This method was chosen because researchers have access into the object of research. Researchers also as a tool (instrument) research (Moleong, 2000: 4) because it can perform in-depth interviews (in-depth interviews) with the policy makers at an object, the full observation and cast as observers.

The focus of this research is a strategic effort to improve the performance STKIP PGRI Tulungagung with the perspective of the Balanced Scorecard. Target point of this research is the improvement of financial and non financial performance that is based on the financial perspective, customer perspective, internal business perspective and learning and growth perspectives.

The reason for choosing STKIP PGRI Tulungagung as field studies because, a) STKIP PGRI Tulungagung as organizations that provide public services and can be evaluated with the four perspectives of the Balanced Scorecard, b) the opportunities this research is done very effectively as any data of doubtful validity can be as soon as possible retested in the field. This is done because there is no longer distance between researcher and research subjects (key informant).

This study requires data between other

a. For financial perspective: the organization's strategy (STKIP PGRI Tulungagung) financial data such as financial statements for the level of income

b. For the customer perspective: student profiles by region of origin, student profiles of workers and not workers, the development of the number of new students, the level of student satisfaction, the number of student development

c. For internal business perspective: the development of the number of majors or courses of study, the activity of lecturers, the number of use of the method, the use of media, the proportion of curriculum and courses, workshops curriculum implementation, the number of graduates, the number of average GPA of graduates, the addition of physical facilities 
d. For learning and growth perspective: employee satisfaction index, kualias lecturers through education level, rank, teaching experience, age of faculty, administrative staff quality through the ages, levels of education, and work experience.

According Lofand and Lofland (Moleong, 2000 ; 112) that the primary source of data in qualitative research is that words and actions, the rest is additional data such as documents and others. Sources and data collection techniques in this research is interview and documentation.

Interviews were conducted by determining the key informant were selected by purposive sampling. Key informant who serve as a resource is led university to know the vision, mission and strategy STKIP PGRI Tulungagung for the future. Interviews will also be conducted to the employees who will be selected by purposive sampling to determine the level of understanding of the vision, mission and strategy of the organization (PGRI STKIP Tulungagung). The interviews were conducted with unstructured interviewing (Moleong, 2000; 138). Unstructured interviews will be conducted with no formal interviews. This interview was conducted so that the respondent was not awkward in expressing the truth. These conditions must be maintained because of the reliability and validity are important in the implementation of the study.

Documentation is done by documenting evidence about the number of students in the last four years, the market segment STKIP PGRI Tulungagung, the amount of training and rank which is owned by the employees.

After getting the required data then the data analysis steps are as follows:

a. Knowing the vision, mission and strategic goals STKIP PGRI Tulungagung then clarify and break them into four perspectives Balanced Scorecard

b. Determine the strategic objectives and performance measures, which are grouped into each perspective. Performance benchmarks used to measure the success of strategic objectives, which in this study are grouped into Lag Indicators as a measure of achievement of success of the organization, and Lead Indicators as a measure of performance triggers

c. Setting a target for every existing measures and alternative strategic initiatives that can help achieve the intended target, strategic initiatives can be re-engineered and work programs

d. Make the appropriate balance scorecard models and simplify the application, so it can show the relationship between each perspective shown by the analys is of causality

\section{RESULTS AND DISCUSSION}

In general, the implementation of a balanced scorecard in STKIP PGRI Tulungagung as an educational institution refers to the strategy adopted. Prior to implementing the existing framework, this chapter is defined vision, mission, goals, and strategies of STKIP PGRI Tulungagung and parts in STKIP PGRI Tulungagung as the bas is for determining the performance measures and targets to be achieved in accordance with the section responsible for achieve its vision and mis sion.

\section{Measurement Performance with Balanced Scorecard}

Performance measurement can be done by doing the translation process in the balanced scorecard to measure performance. The process can be carried out by translating the vision, mission, goals STKIP PGRI Tulungagung into three areas 1) What financial goals STKIP PGRI Tulungagung?; 2) what is critical to providing value to the consumer? ; 3) What do the STKIP PGRI Tulungagung in serving customers and how to attract and serve these consumers?. Based on these three things it will be associated with each perspective in balanced scorecard.

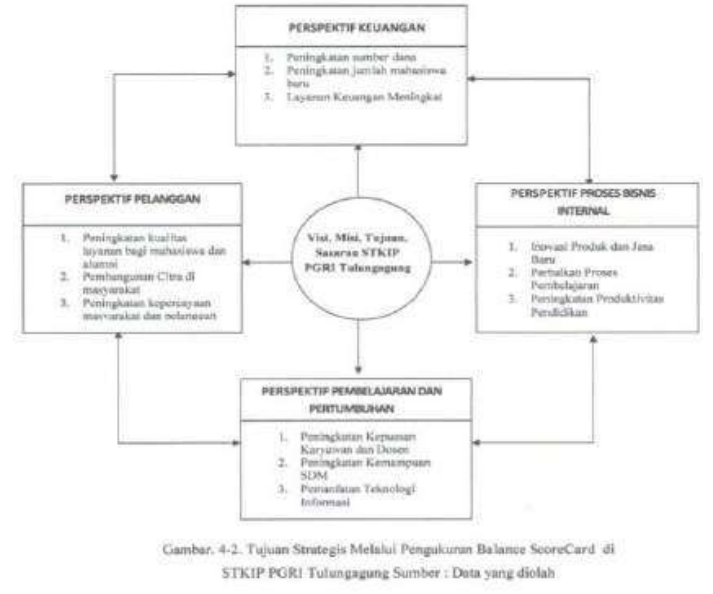

If the image above and the discussion of the four perspective Balanced Scorecard described more fully into strategic objectives, benchmarks, targets and strategic initiatives can be presented in Table 1 below: 
Tabel $4-1$

Rancangan Model Balance fconcant di STKIP PGRI TULNGAGING

\begin{tabular}{|c|c|c|c|}
\hline Tijanstrnteqgi & Tolkt ther & Torgt & Isitivet stontege \\
\hline 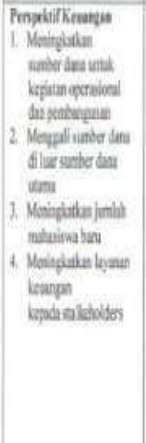 & 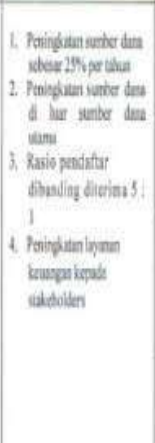 & 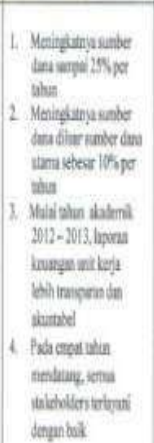 & 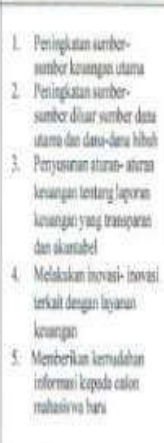 \\
\hline 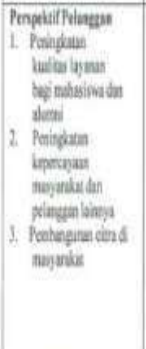 & 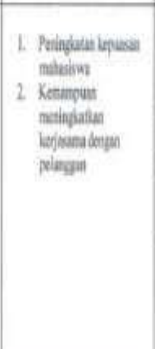 & 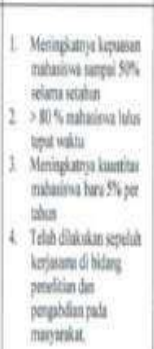 & 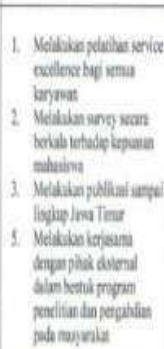 \\
\hline 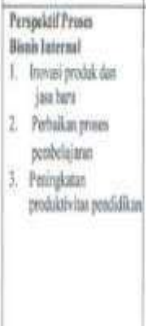 & 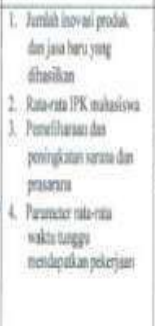 & 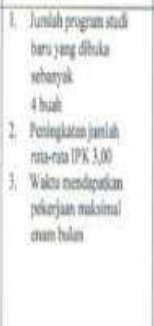 & 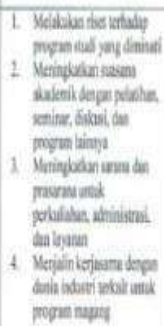 \\
\hline
\end{tabular}

\begin{tabular}{|c|c|c|c|}
\hline 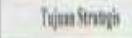 & Tidelar & Turnt & litalti (Mnitegh \\
\hline 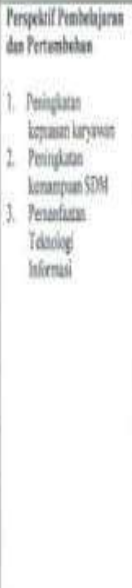 & 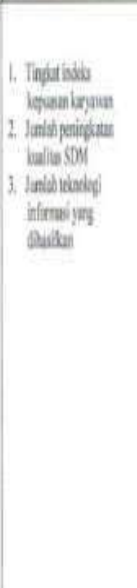 & 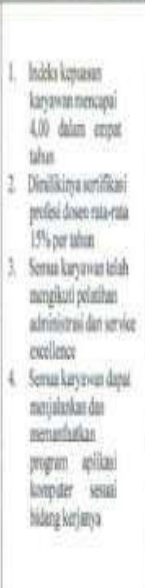 & 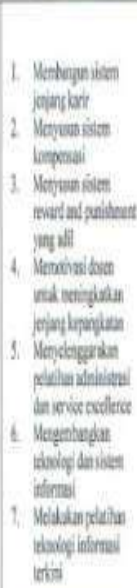 \\
\hline
\end{tabular}

Sunber: Hasil Amlisis

\section{CONCLUSION}

Based on the research results can be concluded as follows: a) Preparation of Balance ScoreCar $\mathrm{d}$ framework can assist in translating the vision and mission into objectives, benchmarks, targets and strategic initiatives. It is important for all organizations including STKIP PGRI TULUNGAGUNG will always be able to provide educational services to the community; b) application of Balance ScoreCard in STKIP PGRI TULUNGAGUNG done by analyzing the vision, mission and strategic goals STKIP PGRI TULUNGAGUNG which is then translated into the strategic measures, targets and strategic initiatives. It is expected to provide measures in the form of a program of work-work programs that can improve the performance STKIP PGRI TULUNGAGUNG overall in achieving the vision, mission and strategic goals STKIP PGRI TULUNGAGUNG; c) measurement of the balanced scorecard in STKIP PGRI TULUNGAGUNG done with four perspectives namely financial perspective, customer perspective, internal business processes, and learning and growth perspective. The results were as follows:

1) Financial perspective: (a) Increased funding sources for operations and development as indicated by the increase in funding sources by $25 \%$ per year; (b) Dig a source of funds outside of the main funding sources are indicated with an increased source of funds outside the main source of grant funds; (c) Improving the accountability and transparency of financial management indicated by can diverifikasinya financial report unit up to the evidence base; (d) Improving financial services to stakeholders indicated by an increase in services to stakeholders and financial services innovation; and (e) provide ease of information for new students

2) Customer perspective: (a) Improving the quality of services to students and alumni as indicated by the increase in student satisfaction; (b) Increased public confidence and more ditunjukka customers with the ability to increase cooperation with other customers

3) Internal Business Process Perspective: (a) Innovation new products and services as indicated by the number of product innovations (in the program) and the new services generated by STKIP PGRI TULUNGAGUNG; (b) Improving learning process as indicated by the increase in the average GPA of students, the average acceleration time of completing the study; (c) Increased productivity of education shown by 
the improvement of facilities and infrastructure, and an increase in the average waiting time to get a job

4) Learning and Growth perspective: (a) Increased employee satisfaction shown by the increase Employee Satisfaction Inde; (b) Increased human resource capacity indicated by the number of improving the quality of human sumbe; (c) the use of information technology as indicated by the number of produced and utilized technology

\section{Suggestions}

In order to implement the Balanced Scorecard in STKIP PGRI TULUNGAGUNG required commitment and support of all employees ranging from top management to employees at lower levels. It should also be followed by a paradigm shift all employees on the balanced scorecard concept of customer satisfaction and employee satisfaction. Dissemination of the concept of the balanced scorecard should do before applying these concepts in performance measurement. STKIP PGRI TULUNGAGUNG must have a planning and development agency specifically tasked to formulate the vision, mission, goals and strategic objectives to further facilitate coordination with all work units. The organization also coordinates the annual work program all work units based on a strategic plan that has been set. But these institutions need to be supported by all the units so that the functions of management of the organization to run smoothly. To be able to know the progress in the implementation of the Balance ScoreCar $\mathrm{d}$ review mechanism effective and efficient must be established so that the organization regards the achievement of specific benchmarks and analyzes it to find the cause of problems and make necessary improvements

\section{REFERENS I}

Clinton, B Douglas, and Ko-Ceng Hsu. September 1997. JIT and The Balance Scorecard : Lingking Manufacturing Control to Management Control Management Accounting.

Dawe, Tom. 2007. Performance Management and Measurement in Small Communities : Taking The First Step Towards Implementing a Balance Scorecard Approach. Government Finance Review. Chicago. February

Garrison, Ray dan Norren, Eric W. 2000. Akuntansi Manajerial. Jakarta : Penerbit Salemba Empat

Gaspersz Vincent. 2003. Balance ScoreCard Dengan Six Sigma. Edisi Kedua. Jakarta PT. Gramedia Pustaka Utama.

Kaplan, RS dan David P Norton. 1992. The BSC Measures That Drive Performance.

Harvard Business Review. January - February

Moleong, Lexy J. 2000. Metodologi Penelitian Kualitatif. PT. Remaja Rosda Karya. Bandung

Mulyadi. 2001. Balanced Scorecard. Yogyakarta: Salemba Empat.

Norton, David P., Kaplan, Robert S., 1996. The Balanced Scorecard: Translating Strategy Into Action. HBS Press.

Parmenter, David. 2007. Performance Measurement. Financial Management. London. February.

Riyanto, Bambang. 1997. Dasar-Dasar Pembelanjaan Perusahaan. Edisi Keempat. Cetakan Ketiga. Yogyakarta : BPFE

Riyanto, Yatim. 2003. Penelitian Kualitatif. Penerbit SIC. Surabaya

Syafarudin, Alwi. 1996. Alat-Alat Analisis Dalam Pembelanjaan. Edisi Keempat. Cetakan Pertama. Yogy akarta : Andi Offset

Zingales, F., Rourke, Anastasia O., dan Hockerts, Kai. 2002. "Balanced Scorecard and Sustainability, State of the Art Review". France: Working Paper, Center for Management and Enviromental Resources. 